ナレバ他日報告ノ機會アルペシ。其他同種移植 ニ關シテモ目下續行中ナリ。

\section{9. 頚部淋巴腺並二舌根扁桃腺二原發} 七ル淋巴系統疾患ノ一症例

\section{特二咽喉部ノ臨牀並二剖檢的所見}

砂田知一(约大)

淋巴系系統組織 7 侵又各種次患, 類症鑑别八 困難ナルモノ多シ。本庭例八琶性淋巴肉芽腫ノ 1 例ナルモ，患者，主訴が，㸶喉部二終始シ。 入院時ヨリ死，轉蹛ヨトリタル約 8 5月 $=$ 亘ル

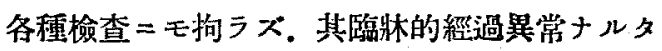
メ診断ニ迷ヒタルモノンジ特二興味フ感ジタ

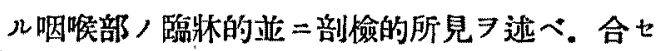
テ必要ナル全身所見フ述ベタイ。

患者八60歳女。遗傅的關係二認ムぺキ點ナ

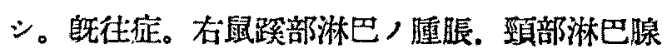

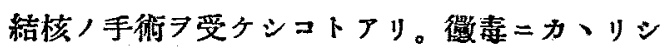

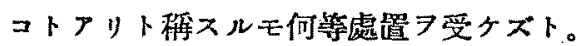

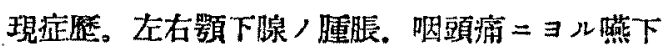
困難，呼吸困難 腋㸗. 兩侧鼠蹊部及ビ 鑽骨上部淋巴腺，小指頭

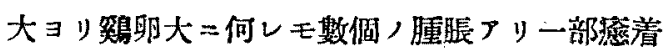

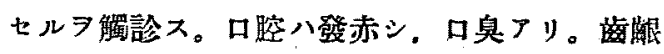
ニ八變化ナク. 左側口蓋扁桃腺八强度,腫脹及 ビ灰白色八被琵つリ，右侧八輕度，腫脹アリ。 舌根部八强度 $=$ 腫脹シ特二左側二著明ニシテ。 其左側中央部二小互大，溃湯厂リ非出血性 =シ テ灰白色，被得アリ。䚡診スルニ彈力性硬度.

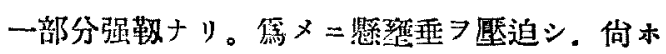
會厭部习厴迫スルタメ二喉頭习检查シ得ズ。體 温八多々 $36^{\circ} \mathrm{C}$ 代二シテ時 $=2,3$ 日 $37^{\circ} \mathrm{C}=$ 上 昇七几事アリタル二. 死, 2 多前ヨリ弛張熱 型フトリテ $39^{\circ} \mathrm{C}=$ 上显七り。數回ノ卫氏反應ス
ベテ陰性. マント一氏反應陰性。尿二變化ナク

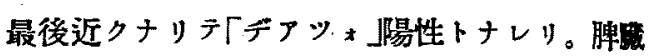
八解知シ得ザリシ事モ

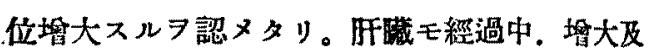
ビ縮小フリタリ。試驗的切除 7 舌根部. 頚部。 腋營. 鼠蹊部二於テ數回行ヒタル二。割面八灰 白色. 中央部鞍但シ謴癔ナシ。 組織像八結䋨織，増加．肉莱組織，增殖，巨態 細胞ノ出現. 輕度ノ「エオジン」啫好細胞/增加 フ認メタルモ。該組䅧ノ「オキシダービ」反應八

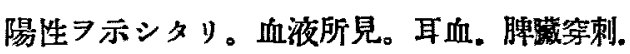
骨路穿剌 $ニ ヨ ル=$ 赤血球數ハ死ンド最後マデ移 動及ビ變化ナク．白血球八多ク正常數. 時= 10000 前後, 增加习認 $\times$ 中性嘈好桿狀細胞，增 加.「エオジン」㖺好細胞ノ增加つリ。「ミェロフ

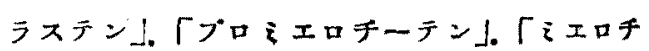
一テン」八經過/前牛期二出現シ. 後牛期 $=$ 出 現セズ。淋巴球八前牛期中八變化ナク末期二娍 少七り。大單核及ビ移行型八常二管加七り。濑

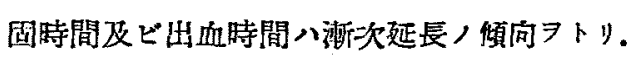
沈降速度八速進セルラ認メタリ。患者八呼吸困

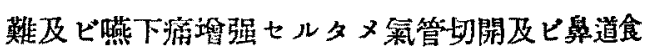
毁 $\ni$ 行七。過剩「レ」線治療及ビ砒素劑內服 $=$

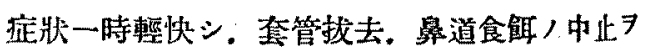

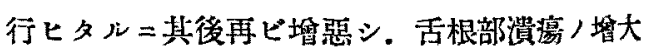
及ビ出血. 縱隔藚嗹瘍, 發現. 腹部膨潇等フリ テ鬼籍二入ル。

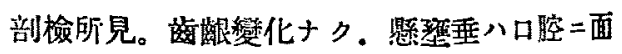
スル部分發赤小豆大ノ潰瘍〉リ。咽頭後壁八正

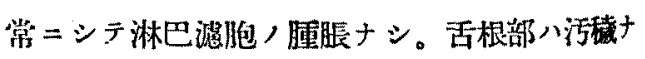
儿溃演狀习呈シ左八左側口蓋扁桃腺ノ一部二及 ビ右八舌，正中線ヨリ約 $1 \mathrm{~cm}$ 右側 =及ビ後部》 會厥，直前二至儿。溃場八清黑色 $习$ 呈シ其周造 
組践 ア形成セル部分八硬ク且ツ堤防狀二隆起シ

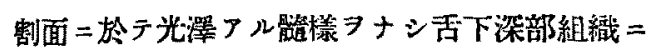
及プ。右側口䕊扁烑腺八萎縮シ。左側ニテハ輕

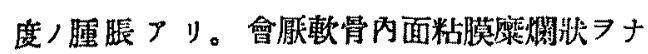

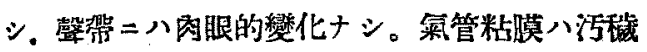
青色 7 呈シ粘桐ナル粘液少量附着ス。企身的淋

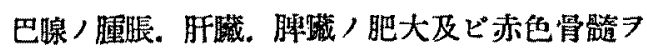
認ん。組織學的所見トシテ左側頚部淋巴腺，口 蓝扇桃腺，舌根部、會厭軟骨部、氮管等二於ヶ 儿肉茅組織。結䋨織, 窗殖. 巨態細胞, 出現。 各璉形態的二非定型的細胞ノ浸潤.「エオジン」 嘹好細胞ノ出現

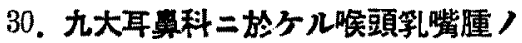

統計的萑察 石 川 慧 助(九 大) 㩔頭乳跴腫, 臨牀的報告 7 観ル二歐米二於テ 八相當多數例二亘りテノ統計的篗察フレドモ。 本邦二於ケルモノ二米ダえレ有ルフ聞知セズ。 特二臨林的見地二立脚七儿該腫，發生原因湴二 治療法二關ス儿諸家，見解ハ末ダ一致セザルモ ノアリ。茲二於テ余八九大耳鼻科臨牀過去 28年 間二於テ入院加療七几該腫患者, 25 症例二就

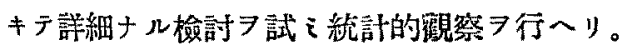
一般乳嘴腫卜同溙喉頭，該腫二於テモ真性瘇演

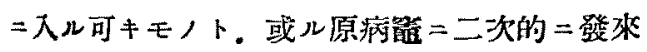

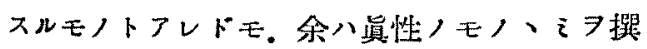
定七り。余/筧察七几諸條項中主要ナルモノ 述ブルニ次ノ如シ。

1. 發生頻度。歐米諸家 スレドモ余ノ場合 $=$ 於テ八喉頭 $=$ 發來スル良性

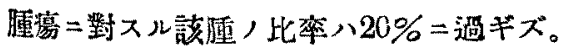

2. 性別。學者二体リテ男子ガ多數ナリト梅 、及ハ略了同數ナリト云ヒテー致七ザルモ．余 場合ニアリデ全柾例中男子ハ17 例(68.0\%)

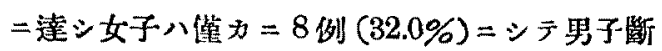
然多數ナり。

3. 年蒢別。特 $=$ 幼年者 $=$ 多シト八定說ナル ガ之ト同樣ニシテ 1 歳ヨリ10歲迄最多數ニシテ

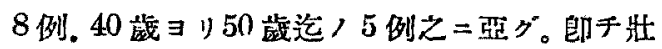
年期ヨリ初老二亘りテハ幼年者二亞グモノナル 䚣儿。

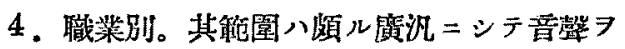
特二過勞スルモノ=軍人 1 名. 敨員 2 名习算七 y。

5. 遗傳的關係。患若/同胞 2 名ガ結核二テ 死亡セルモ，1例，叔父又八叔母カ結核二テ死 亡七ルモノ备 1 例アリ。更二惡性腫㸃二關シテ 八祖父ガ胃癌二ラ゙死亡七ルモ，1例．母が子䈍 癌ニテ死亡セルモノ1 侧ア見ルニ過ギズシテ大 多數二於于同種，腫瘍八勿論他，腫揚，造傅的 關係习認ムル事能ハズ。

6. 健康狀態。生來虚弱ナリシ者八僅カ $=6$

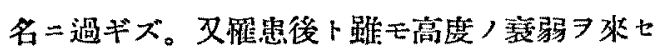
ル者ハ僅少ナリ。

7. 既往症。「チフス」フ殌過セルモ，2例。 肺炎ヨ䓫メル事アルモ，2例.「デフテリー」. 赤婌ラ經過七りト云つモノ各 1 例アリ。

8. 原因的疾舁。感目後二縹發セリト云フモ ノ多數ニシテ11例フ算スルモ患者，口述二低ル モノナレバ正確ナラズ。原因不明卜稱スルモ， 又12例二及ビ內先天性卜思ハル、モ，2例了 リ。特二哳腹/原因卜直接關係アリト認么可キ モノニ「デフテリー」隶患後， 1 例及ビ音罄過勞 後ノ1例厂リ。

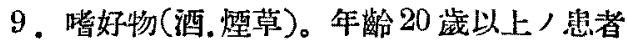
13 名中飲酒家八 6 名. 契煙家 5 名ニシテ何レ モ少量刃八中等量习饮用スルモノ、 